\title{
MAPPING THE RELIGIOUS RESPONSE OF THE DISASTER-HIT COMMUNITY: (REDEFINITION OF RELATIONSHIP BETWEEN HUMAN, GOD, NATURE AND RELIGION IN DISASTER CONSTRUCTION)
}

\author{
Ibnu Mujib \\ University of Budi Utomo, Malang
}

\begin{abstract}
This paper would like to map the religious response in a post-disaster community. In an academic discourse, a post-disaster community is one with abnormal conditions, including how it defines aspects of Divinity in their religious perspective. Thus, the complexity of issues that encompass a disaster-hit community will shape the worldview, perspective, and the understanding of the relationship between human, God, nature, and religion, serves as the basic assumption of this research. So, there are several points that will be introduced in this paper including: first, the disaster typology from the perspective of the experts; second, the debate between the divine law and the law of nature in the context of disaster; and third, the religious response of the disaster-hit community over the history of the events of disaster. The research shows some important findings including the emergence of various forms of response about the events of disaster and their relation to human, God, nature, and religion itself. Since the concepts of disaster appear from a post-disaster society, on one side also require relationship which is able not only to respond to disasters but also to provide constructive solutions to the survival of the post-disaster community. Therefore, the stronger the religious normative doctrine of a person, the more difficult to bring closer to the context his survival not to mention life improvement. Nevertheless, in the majority of other communities that culturally experienced two sides of mass dilemma i.e. the theological concept of submission, patience and gratitude in the religious worldview of post-disaster community as the disaster not only happened to a person but also to many people.
\end{abstract}

Kaywords: response, disaster, relationship, human, God, nature and disaster

\section{INTRODUCTION}

A historic event and full of mystery, in fact, it occurs in a wide range of space and time that is unexplained when and where the event will take place. An expert in religion argued that the disaster occurs as a result of the separation of man from the Devine principles (Schuon, 1995: 43). Another scholar, Peter 
Curson defined a disaster as an event with high magnitude related to the period of normal human experience (Curson, 1989: 8). Disaster is also interpreted as a phenomenon primarily associated with natur and separated from human's daily experiences and ordinary human activities (Hewitt, 1983: 6 ; Anderskov, 2004: 10 ). The three definitions above explain the nature of disaster described as a condition for the abnormality of nature and human.

This abnormal condition, on the one hand, brings the impacts to social environment and psychological condition of human beings, and on the other hand causes vulnerability resulting in things that are not only related to ownership and economic resources but also to the population growth, urbanization and changes in human behavior (Curson, 1989: 4). Even in another sense, disaster also has an impact that stimulates the imagination in creating various backgrounds of speculation on human (Curson, 1989: 1). Disaster also appears to result in abnormality to facilities and social structure, and other destruction including deaths, mental disorder, disability, loss of property, or in the form of damage to social processes, such as production systems, division of labor, norms and social roles, national and international politics, as well as in the form of hope, motivation and opinion (Blaikie, 2002: 299).

Here, abnormality of nature has given rise to changes in human behavior, evidenced by the feeling of fear, anxiety, worry, and many people even start to search for God through prayer, plead for help, even blame each other, not only blaming the victim but also blaming God, where both expressed with different forms of acceptance and compliance. The form of blaming the victim can take various forms, for example a singer named Ebit G Ade with his "Maybe God is beginning to get tired of seeing our behavior," Bimbo and later Sherina with their lyric that roughly reads: "Your curse is so profuse, it is indeed our fault." In religious sermons, we also hear of the same tendency in responding to disaster. Even illustrations of mourning songs often played on TV stations, for example, almost always lead to cynical tones. Meanwhile, even groups of people also blame God. An article in the New York Times entitled "Where was God?" indicated that people are starting to question the direct intervention and effect the instant of God's activities.

In monotheistic religions, the reasons people gave for the justification of the occurrence of disaster are based on many things. Some people refer to it as a form of God`s punishment because of human sins. Some also call it a warning because God occasionally wants to see the strength of faith of His servants. A more extreme disaster is also referred to as a test from God to 
his servants. The third way of thinking is a reflection of the typology in this study will connect at a symbolic relationship between religion and the disaster.

In another perspective, the reason for the above justification is not always running smoothly. Voltaire (a leading French philosopher), for example, questioned the justice when disaster struck Lisbon (1755), approximately onethird of the population became victims. Voltaire's anger was demonstrated by one of the lines in his poems that reads, "Please show me the justice of this structure when innocent people die, and when innocent people are punished like a sinner?" (Muhammad, Illous, 2006). However, Voltaire's view was appreciated by many --in the tradition of Islam-it is mentioned that damage on land and at sea is due to human action, as in the word of God: Corruption has appeared throughout the land and sea by [reason of] what the hands of people have earned so He may let them taste part of [the consequence of] what they have done that perhaps they will return [to righteousness]. (QS. ArRum 30: 41)

According to the history, for example the story of Prophet Lot, as revealed in the Qur'an where it is mentioned that disaster occurred to the people of Prophet Lot because of homosexuality. Despite the historical interpretation surrounding the story, accompanied by the emergence of homosexual myth for the first time on earth, it is revealed that God destroyed the place inhabited by the people of Prophet Lot by overturning the mountains. There are several verses that mention that such events were done by God. In another example, it concerns the history of the process of creation of nature. In this case God said that He ruled, and created the universe, with all its contents and set the rules and certain laws in it. According to Fazlurrahman, because the determination these rules, the nature became autonomous. Just as the law of gravity in which this law confirms that something falls not because of the weight of the object but due to the pull of the Earth's gravity. Therefore the tsunami is part of the laws of nature (sunnatullah) which was created in advance.

The debate is now centered on what exactly are the role and position of relationship between human, God, nature and religion in the construction of disaster? If all power lies under God, how does He answer the question about disasters? On the one hand, God is Most loving and Most compassionate, but on the other hand, $\mathrm{He}$ lets if not creates evil and disaster which caused massive loss of life. Two contradictory relationships need to be described in accordance with the respective context. What about the role of God as Most forgiving when innocent people are struck by disaster? Or the does disaster give room for the activity of soul searching that could lead us to a stronger faith? It has also caused a crisis or theological confusion over the 
nature of God's double standard. Other problems also arise when humans become passive due to the construction of "world view" about the autonomy of God becomes dominant in the human response to disaster.

\section{PORTRAIT OF A TYPOLOGY OF DISASTER}

Prior to reviewing the mapping of shift religiousbehavior of the society, this study began with the discussion of the portrait of and various types of disaster as a tool to measure the response and to provide different interpretations. Various issues of interpretation of disaster can be seen clearly in the behavior that indicates numerous interpretations. There are three categories of disaster. First, that the disaster is a process that occurs everywhere as a common natural process. This group looks at the disaster as a natural process that naturally occurs. Tsunami waves, floods, earthquakes, fires, and even landslides happened due to physical changes of the earth. Earthquakes are also a process of shifting earth fault. Volcanic eruption is also a regular volcanic event. So are floods, this is only a problem of risk management of the flow of water. Fires also occur as an ordinary negligence that can happen to anyone. Including the tsunami, which is also a normal effect of the sea floor movements that create longitudinal and transverse waves.

Human asserted that during a hurricane in the UK in 1987, the conception of nature as a controlling factor gained the affirmation: "Nature has been acting destructive, irresponsible, destroying itself and dragging everything with it. The end of the world occurs at this point and no one can stop it, broken glass, falling objects and all the noise cannot be tolerated, every living thing has come to a stop" (Homan, 2003: 150). It is also pointed out that disaster is part of the natural process that follows its own laws including the huge flood that hit the people of Noah which was a model of ancient tsunami. Destruction of the Prophet Lut's people, landslides that claimed a lot of lives, the event when Moses crossed the Red Sea, the destruction of Pompei population were regarded as victims of disaster that could occur due to the rules of nature. The stories of the past are also part of the natural process that occurs when the laws of nature apply. Therefore, all that happened is a natural event, not related to the moral and human behavior. People with this perspective also assume that nature is neutral and not affected by the attitudes and behavior of human beings.

Second, disaster is viewed as the Representation of God's law (God made disaster). This group defines a disaster as a process that emerges from the punishment of God to sinful people. In the terminology of the stages of human thought in religion there are at least three (3) categories, the first stage is the 
common man or the so-called ordinary people; the second stage, the believers, people in position of believing in God Almighty and His Messengers; and the third stage is pious followers of religion i.e. those who are able to perform and execute the laws of God with sincerity. This is in contrast to August Comte who referred to the stages of human religious thought beginning with the theological stage, where the earliest period of human phase began with theological passion. In this context, disaster is more likely to be interpreted as God's punishment, which is imposed after humans break the rules and laws of God. As quoted from John Garvey when responding to the earthquake in Lisbon in 1755, where God used the horrible tragedy (such as tsunamis, earthquakes, floods, etc.) to punish humans (Garvey, 2005: 10).

A little different from the above concept, in the Hindu tradition, the forms of disaster are called karma, or "karmaphala" that is, as God's punishment caused by human actions, either bad or good. In this case there are constant human efforts to tame the nature, be it, in the sky, land or water. For example, when we cut down trees, destroy mangroves etc. and such action will cause an imbalance in the natural process of ecology, which is similar in the tradition of Buddhism that views disaster as an imbalance that occurs in nature. The disaster also has a meaning other than punishment. It is often cited by groups of people whose status in the terminology of religion are known as the disbelievers. These people react to disaster with nrimo (accepting something as a fate). In contrast, the believers interpret disaster as a trial, in which each God will judge a person's patience in dealing with disaster.

Third, disaster is seen as human error (man-made disaster). This section explains that disaster is a direct or indirect result of human behavior and human error. This section also suggests that the environment is not neutral to humans. Environment will give a response back depending on the morals, practices or behavior of each human being. Therefore, all disasters, calamities, or natural events that occurred in relation to what humans have done. Look at what we have done to the environment, for example, hundreds of kilometers of mangroves on the coast of Sri Lanka are gone. Look at what happened in Jakarta or Aceh, Ulele and on other coastal areas in many parts of the world. We have turned those natural areas into a real estate or shrimp ponds. An Islamic contemporary thinker said that man is vicegerent on earth so environmental balance should be maintained, nothing is eternal, not even hell, and only God is eternal. When viewed from the patterns of the flood disaster that hit the people of Noah, it demonstrates that this type of disaster could be God's punishment to those who disobey Him. The destruction of the people of Prophet Lut is a form of God's wrath on the homosexuals. The destruction 
of the city of Pompeii is a reflection of God's anger at moral depravity of the population there- who liked to exchange wives and practice prostitution, visit brothels.

The forms of disaster because of the human error category are among others war, industrial catastrophe, nuclear disaster and political interference, illegal logging will cause flooding, etc. Hewitt, for example, classified the types of disaster into three categories: first, natural disasters (the atmosphere, hydrology, geology, and biology); second, technological disasters (harmful objects, destructive process, mechanical, and productive); and third, social disasters (war, terrorism, civil conflict, and the use of goods, processes, and technologies that are harmful) (Oliver-Smith, 2002:) The focus of this study is on the first category as a subject of religious studies because it can be explained that the second and third categories are not too difficult to understand as human errors (man-made disaster) that no longer require the analysis of religious approach.

With regard to a series of catastrophic events, Irwan Abdullah covered disasters in various places ranging from the form, scene, year to the causes and impact, such as those that occurred in the mainland of China (1333), Japan (1891, $1923)$, the Philippines $(1645,1867,1877,1879,1892)$, Indonesia $(1815,1883$, $1963,1994,2004,2006)$, to Africa (1973-1985), Central America (1970), and United States (1906, 1991, 1992, 2005), in the forms of war, drought, famine, hurricanes, floods, tsunamis, landslides, erosion, earthquakes, nuclear explosions, epidemics, physical damage, loss of property, disability, mental damage as well as damage to the structures and social systems (Abdullah, 2006: 11). According to Irwan, the debate about the relationship between nature and culture has been initiated by the pattern of their interaction that gave birth to a lot of new understandings of dependence and independence of man against nature, and vice versa. Initial views see that nature is something that is separate from man who has undeniable power, so that the natural environment has defined the identity of human, including the category of "the others" due to differences in deterministic environment for human adaptation. In religious approach, more disasters are shown in a mysterious incident in conjunction with the Ruler and Creator of the universe. Frithjof Schuon in his book The Transformation of Man asserted that all human misery (disaster) is the result of our separation from the principles of God. Do disastrous apply for a penalty, trial or test, in which the target group penerimanyapun also very varied and diverse. So do not be surprised if many people are discussing this in the category of post-disaster God debate.

Disasters can also be found in other forms, such as death, mental disorder, 
disability, loss of property, or in the form of breakdown of social structures and social processes, such as production systems, division of labor, norms and social roles, national and international politics, as well as in the form of expectations, motivations and views (Blaikie, 2002: 298). The result of a disaster can also be found in the human behavior change especially related to religious observance, for example, how a religious man is increasingly appreciating the values of the religious spirit, or how disasters even begin to stop him from being religious. Moreover, even man's view of God as most loving and forgiving has also changed.

\section{HUMAN RESPONSE TO THE ELEMENTS OF GOD AS THE CREATOR AND THE MERCIFUL}

Discussion about human perception of God especially in the wake of disaster always bears various meanings, explanations, even categories according to the level of world view which develops in humans, and sometimes also by the environmental and community background that change human's perception of God. One of the world views --even human perception is that God is the sole Creator of the universe/nature that is so beautiful, spacious, and full of a variety of values. Another perception sees God as most loving, which is a trait that is more pro-life. An example that can be shown is that essentially all human needs have been answered by God. A sense of happiness, security, abundant fortune, even when humans become sick under certain circumstances, it is also interpreted as the love of God, because a sick man can take the wisdom of his life journey. It is all an inner experience that man has created through various struggles in life.

Two of the traits of God are being a creator and being compassionate. This means that all of God's creation should be maintained and must be kept with the spirit or the properties of affection of God, not just man as His creation, but also applies to nature and the environment. If we try to hold with the concepts of God over man as a caliph for example, certainly, it is not the creation of the caliphate with the identity of a particular physical form, but the caliphate is a creation of God on man's role on earth. As a caliph, humans have turned the role of nature and all its contents, keeping in touch with each other so as not to break or have conflict. If the role is in accordance with the proper function, the task of the Caliphate is on the right track. The contextualization of man as a caliph is a substitute of God's work on earth. On the one hand, man has a creation capital, on the other hand, he has to subdue and consult the creator. However, this perception has shifted later - after which man's role is precisely controlled by the theological regime particularly religious ideology, in which 
human beings are not liberated again as a substitute for God's work on earth. $\mathrm{He}$ is in a power loss, while God behind this reality is believed to be a decisive Actor in the decisions of human life yesterday, today and in the future, like a puppet controlled by the puppeteer. Humans have set back to see God, in which God is formulated according to the size of a prehistoric society.

Similarly, God is aware of the task, the rules of law given to human to run His task on earth. This divine consciousness is described in the Qur'an that as "Allah will not change the condition of a people until they change what is in themselves." This illustration gives a lesson in human submission that the impact on the real destiny in the context of disaster resulted in the lack of creative response, while, it is a prerequisite or an absolute indication that a people can only be changed if they themselves are willing to change. Such is the nature and role of God's compassion shown to humans through revelation. Related to human perception on playing God in a post-disaster condition, many of the disaster victims who have lost a child, family wealth, etc. now have become helpless to move back to normal life, but what happens is they subject to the fate that shadows life after the earthquake/tsunami. Prolonged trauma is also part of the shadow of destiny and a sense of innocence in responding to disasters. It can be explained that human perception of the role of God as the Creator and the Merciful is derived from human inner experience that is felt when individuals are under normal conditions. The question is how is the current human condition in abnormality? Will he feel the same when he is in an abnormal condition such as a disaster?

Abnormal conditions often present a variety of new forms, i.e. the shifting paradigm of the meaning or certain religious symbols. Human perception of God in post-disaster condition (not normal) is different from that under normal condition. At the same time, it is undeniable that a disaster is always followed by a series of questions both philosophical/cosmological and theological. The philosophical-cosmological thought attempts to link the various phenomena of the natural world with the "anger of the gods" as a result of an imbalance in the structure of the cosmos. On the other hand, theologically Christians see it as the issue of the implementation of the infinite divine power, which in Islamic theology is called "destiny or divine decision based omnipotence" or "trial of God" and therefore should be accepted wholeheartedly with sincerity and submission. Meanwhile, Hinduism understands disaster as part of the process without end (samsara); in contrast to Buddhism which understands it as $d u k k h a$, "part of the circle of human life: suffering, desire, action, result, known as the "Four Great Truths" which form the basic structure of human suffering. 
Haidar Bagir (2005) in an article in Kompas Daily stated that crime is the effect is required of virtue. Virtue is not possible without an absolute evil that comes from it. Fire, for example, is a good for cooking, keeping us warm, and many other good purposes but at the same time a fire has the power to destroy valuable things in certain circumstances. Then, crime is an inevitable consequence of the existence of some good; abolishing it means at the same time eliminating the cause of it which is good-whose positive values exceed the negative. Contrary to the solution described in the first category, this type of solution, along with three subsequent solutions, do not reject the basic components of theistic teachings. All of the natures of God are maintained and considered absolute; crime is also recognized as a fact in society. Many seek to justify that God causes or allows crimes. Haidar argued that crime is also a necessary means to good. According to this view, evil is always the case in order to bring something better than the existing ones. Slapping a child, for example, is a crime, but is useful to discipline him. Earthquakes, floods, fires, and other disasters are also a crime, but all of them have good effects, such as lowering the population, teaching people how to face suffering and distress that may lead to events both in relation to the universe as a whole and kindness we do not (or may not) understand as a favor. With such perspective, this type of solution is referred to as the "defense of the higher good".

Nelson Pike ("Good and Evil", ibid) (1964: 111) is one of the well-known supporters of the 20th century to the "defense of the higher good". Pike stated that this solution does not come "from an acquisition that an excellent form will prevent suffering, if it could". Pike argued that something could be good even though at the same time it gives rise to crime, but it should "have a strong moral reason" to do so: for example, a father who gives his son a spoonful of bitter medicine should not be blamed because he is doing so in order to cure his son of disease. Taking medicine is an unpleasant experience for the child and, therefore, is a kind of evil, but it is a means for the higher good: to restore the health of a child. Thus, a father, although responsible for giving drug to his child, is free of errors that lead to crime: he has a "strong moral reasons". Pike found that the same argument can be applied to God. God who has knowledge of the suffering experienced by certain creatures and has the power to prevent such suffering-but He still does not prevent it. However, God cannot be accused of doing evil: God who causes or does not prevent a crime actually has the aim of producing higher good for individuals who experience crime, or for the universe as a whole. In other words, if God prevents some crimes, He also prevents some higher good.

Nevertheless, to some people, the analogy between man and God could give 
rise to further questions. It is difficult for a father, with his human limitations, to treat diseases without giving his child bitter medicine. However, God is considered to have absolute power and, therefore, must be able to generate good without having to use a means of crime or damage. The problem is that if it has become a framework that should be accepted, it will present similar form of inconsistency on the nature of God or God is in the status of double standard, and at the same time will give birth to confusions over the theological dogma of the religion one practices.

\section{NEW PARADIGM OF DISASTER THEOLOGY}

The phenomenon of religion or post-disaster religiosity has changed in many ways. One of them is human understanding of God. God is always defined as the Omnipotent or capable of controlling the entire universe (the ultimate reality). In addition to God as Creator, He is also Merciful. In this sense, God does not take sides on any position, whether people are on His orders, dissidents, or even someone enjoying the pleasure against the rules outlined by God in His Scriptures. In addition, God is also interpreted as the creator of destruction. The most recent understanding of this, at least, is represented as the most recent understanding in the wake of structural damage of natural, social, or material as the impact of the disaster.

Human understanding of God in the post-disaster time appears in various ways, not only the response of the clergy, but also the indigenous groups to the smallest entity of social structure. It is normal that when disaster strikes, the majority religious community, including from Muslims, Christians, and Catholics usually holding a joint prayer with the aim to prevent the disaster from happening again in the future and for victims to immediately return to normal life. In contrast to the Hindu tradition, although also having the same goals, they have their own way of giving offerings through typical rituals and ceremonies, which are dedicated to the gods believed to be the god of destruction maker.

Unlike the indigenous groups, in Java, for example -through the Javanese culture stakeholders, the representation is also shown in a unique way that is usually delivered shortly before the arrival of the disaster. Including when there is a mystical sign of the coming of pagebluk (disease) that will befall the society, suddenly the pandeta Sri Sultan Hamengku Buwono ordered to prepare lodeh (vegetable dish)with 9 nine types of fruit or vegetable as a preventive therapy of disaster that might come later. Such mystical or even religious therapies can be viewed as the logical form of a series of human religious experience that is always repeated over and even its existence is 
never questsined, although its development is manifested in the forms of myths that are always attached to the rituals. This sort of phenomenon will also experience the dynamics and development, and if observed, the rites performed at Mount Merapi will have different ways, kinds of rite, meaning even there are certain forms of ceremonial rites performed for earthquake safety. To tell the difference between the two is not only the significance or mystical symbols in them, but they also have a systemic network which runs continuously between the macrocosm (nature), myth and rituals (Pall, 2000).

\section{DISASTER: SPIRIT FOR MASS REPENTANCE AND IMPROVEMENT OF LIFE}

What exactly is the repentance? It is usually done by human when they realize that they have done a lot of mistakes and sins in the past. Therefore, in general, repentance is done after trial occurs. However, the orientation of the repentance is that in future one no longer makes the same mistake. According to Ignas Kleden (Kompas, March 13, 2007), if someone made a mistake, and the mistake was big enough, then in the consciousness of the person concerned appeared at least three psychiatric reactions to his actions. On the first level, the person will experience internal battle within his mind, loss of balance, and suffering from disharmony that made him feel his life is in vain. In the following stage, disharmony will bring people to repentance, which is a kind of hope that what has happened should not happen again.

However, according to Kleden, as behavior, regret is still oriented to the past, particularly to crimes or mistakes that have been done, which are expected not to occur again. Perhaps, because of the sins committed and errors made, Indonesia is increasingly getting worse today. In fact, Indonesian society is in a position that is increasingly suffering from disaster. No wonder novelist Andre Vitchek cited by Azyumardy Azra wrote that Indonesia is now replacing Bangladesh and India as the most vulnerable countries in the world in terms of natural disasters that claim so many human lives. According to him, Indonesia has now become a "mass killing field" because since the tsunami in Aceh in December 2004, Indonesia has lost more than 200,000 of its citizens in a variety of natural disasters; This figure does not include those killed in highway and communal conflicts, such as in Poso. With that figure, disaster victims in Indonesia in the last three years were more than those killed during the Iraq war, or civil war in Sri Lanka, or in Peru. (Kompas, March 13, 2007).

Regarding the fact, theoretically Tylor asserted that the conditions of human abnormalities have resulted in many things, one of which is a sense of regret. Repentance is a process of transformation or normative forms of remorse which 
is referred to as feedback on the condition of abnormalities or irregularities that cause human beings to be in chaotic state. It is this state, Tylor said, in its primitive culture forming part of the myth or myths that at the same time always accompany the rite activities, where it is present and formed by an order from the chaos caused by the condition of the regular macrocosm. The sequence of the macrocosm, chaos, myth and rites according to Tylor occurs continuously in the process of human religiosity even in prehistoric times (Tylor, 2000: 31).

As a result, in line with what Azyumardi Azra found that sort of thing is not very effective, for example the national repentance ritual, Istighosa, mass recitation, ruwatan can only bring momentary psychological serenity; because religion does not provide instant solutions to problems face by humanity.

We can simply understand what is presented by Azra in a statement above. Nevertheless, the problem is that the spirit--including mental affairs or in the context of repentance-- always brings human internal factors intensely. Nobody can determine the level of one's spirituality. Humans are basically open in various levels of spirituality; first the spirit associated with steps formulated by A. Comte namely, first, the theological level; second, metaphysical level, third what he calls positivistic level. It is on this third level that humans try to provide space on revitalization efforts in the post-disaster life, rather than accepting destiny that tends to be passive and less responsive to management of disaster.

Communal disaster has created a new meaning that constitutes a total change of normal human condition into an abnormal structure. The case of the earthquake and tsunami that hit Aceh in December 2004 can be made as a frame of reference in view of the meaning of a disaster. According to the data the incident took more than 236,116 human casualties (Tim Satkorlak NAD, 2005). It did not stop there. Thousands of social sectors (housing, education, health, religion and culture), infrastructure such as transportation, communications, water and sanitation and production sectors such as agriculture, fishing industry and trade, were also destroyed (Bappenas, 2005) also have been victims of this tsunami. An earthquake of 8.9 on the Richter scale not only caused destruction to material buildings and residential population and other social facilities but also resulted in the loss of economic opportunities, and mental injuries suffered by the people of Aceh in general, have also left problems in Aceh recovery process in the future.

A number of social problems began to emerge, especially for those who are still alive, some disturbed deterioration of health, loss of family, loss of property including residential and business, as well as loss of evidence 
of ownership of the property, such as land certificates, deed of purchase, Vehicle register, certificates of deposits and shares (Ismail, 2005: 7). Not to mention the presence of a variety of institutions such as NGO's both local and international, where their arrival not only provided programs of recovery, but also sometimes brough with them values of the different cultureas everyone has a cultural different sensitivity.

However, what's interesting is that the complexity or the crucial issues that disaster has basically become the event that was not borne individually, but felt together among victims on the one hand, not to mention a sense of empathy that came through various donations that also indicated that they are not alone. On the other hand, disaster led to a form of inter-individual choices in determining the fate of their victims after the disaster. The reaction was not only marked by the completion of the physical problems but also targets nonphysical issues, including the relation to changes in lifestyle of the people after the disaster. In an ideal and normal dimension, the desire to choose a better way of life is chosen by many people on the one hand, but on the other hand, the trauma that has not been fully gone has led to a new stage in the form submission to the Creator. It should be underlined that the two sides of the mass dilemma experienced by the victims of disaster have agreed upon the concept of the nrimo theology in the religious world view of the post-disaster community.

The dynamics in determining and selecting religious concepts in a postdisaster condition also appear in various ways. When observed, we can come up with three ways that people respond to disasters such as nrimo, patience and gratitude. The concept of nrimo - is an attitude of total submission without any concrete/tangible efforts. This attitude is backed by a normative selfawareness of disaster actors in understanding the complexity of the problems surrounding them by laying the foundations of a short-term expectations called survival strategy. However, the concept of nrimo then may shift toward guarantees and collective sources. With the new mobility, many people came to help, and social organizations are also involved. With a variety of existing mobility at the same time it has generated a new spirit and imagination to form a future related to them, even the significance of their lives were also determined by the presence of diverse complexity that would affect their psychological background. Similarly, other attitudes or responses will continue to experience a change in its context respectively.

\section{CONCLUSION}

Discussion about religion and other disasters is not the same with regard to the 
viewing disaster from two perspectives at once, i.e. scientific perspective and religious perspective. The scientific perspective views nature as the objective world. Facts are subject to the laws of nature. However, humans do not see nature only as facts, but also as the world they live in. The religious perspective, however, views nature in relation to reality and existential appreciation. It means that nature is not a factual truth, but it is seen as a formula of a transcendental truth. Both generate the meaning of the same truth, though at a certain stage there are relationships that mutually determine a context of disaster. Similarly, tsunami, from a scientific perspective is an event that can be objectively calculated geologically. On the other hand, the religious perspective sees tsunami as an existential and transcendental encounter with things that cannot only be measured with geological formula, but in the religious context, it is beyond rationality.

In this context, Moltmann indicated that the perspectives of theology and religion will face two kinds of crisis: relevance crisis and identity crisis: that the more theology and religion try to maintain the traditional and rigid dogma, the more theology and religion will side with the context, and thus it becomes less credible. On the contrary, theology and religion put themselves as the "panacea" to end the suffering, - unfortunately when theology and religion itself failed to respond to disaster-- then theology and religion will lose their identity. Thus both these crises ultimately have the potential to bring up an attitude of distrust between the two.

Hence, the concepts that come from a post-disaster community, on the one hand, also require relationships that are not only able to respond to disaster but also provide constructive solutions to the survival of the community in the wake of disaster. Such a concept depends on how human beings explain the relationship between religion and disaster, whether disaster is regarded as a punishment, trial or test. All three will give produce a wide variation in understanding the disaster. When disaster is understood as a divine punishment, then the disaster is tangible as a form of karma for human errors made in the period of life. In contrast to the caliphate concept proposed by M. Iqbal in interpreting disaster, among others, he explained that when God has given trust, mandate to man, then man cannot be held responsible for his mistakes, let alone as whole.

"Good and Evil" written by Nelson Pike, at least provides another color in interpreting the context of disaster (the defense of the higher good). It is a concept that does not come from "a notion that an excellent form will prevent suffering". However, this argument indicates that something can be good even at the same time it gives rise to crime, provided that it should have a 
strong moral reason to commit it. It is similar to the analogy of drugs given to a sick child. Despite the bitter taste, medication will help heal the sick child. Therefore, the study of theology and disaster has made it clear that the autonomous power of God for the disaster must rely upon strong moral reasons, so the power is uncontested even by other moral reasons.

Nonetheless, it should be realized that the complexity and the buzz of crucial issues of disaster, on the one hand, have become an event that is not only suffered by individuals, but it has been perceived as a shared calamity among the victims, not to mention a sense of empathy which is present through various donations that also indicates that they are not alone. On the other hand, disaster leads to a form of inter-individual choices in determining their fate of after the disaster. The reaction is not only marked by the completion of physical problems but also targets on non-physical, including its relation to changes in lifestyle of the people after the disaster. In an ideal and normal dimension, the desire to choose a better way of life is chosen by many people on the one hand, but on the other hand, the trauma that has not been fully gone has led to a new stage in the form submission to the Creator. It should be underlined that the two sides of the mass dilemma experienced by the victims of disaster have agreed upon the concept of the nrimo theology in the religious world view of the post-disaster community.

\section{REFERENCES}

Abdullah, Irwan. 2006. "Dialektika Natur, Kultur dan Struktur: Analisis Konteks, Proses, dan Ranah dalam Konstruksi Bencana" in Pidato pengukuhan guru besar FIB-UGM, Nov. Unpublished Paper.

Andreskov, C. 2004. "Anthropology and Disaster." www.anthrobase.com

Bagir, Haidar. 2005. Membincang Keadilan Tuhan (teodice) dalam Bencana Tsunami di Aceh, Kompas 02/02/.

Benson, Herbert \& William Proctor. 2000. Keimanan yang Menyembuhkan: Dasar-dasar Respons Releksasi, Bandung: Kaifa.

Blaikie, P. 2002. "Vulnerabilityand Disaster" in V. Desai and R. Potter (Eds) The Companion and to Development Studies. London: Arnold.

Durkheim, Email. 1992. The Elementary Forms of the Religious Life. New York: Free Press.

Eva Illous, 2006. From the Lisbon Disaster to Oprah Winfrey Suffering as Identity in the Era of Globalization.

Garvey, John. 2005. Is God Responsible? The Tsunami and Other Disaster. Commonweal; Academic Research Library. 
Hardiman, Budi. 2002. "Posisi agama dan sains, in Artikel Seminar "The Future of Religion-Science Dialogue". Jakarta: Universitas Paramadina. (Rabu, 13/12). Kompas.

Hewitt, K. 1993. Interpretation of Calamity, New York: Allen and Unwin.

Homan, J. 2003. "The Social Construction of Natural Disaster: Egypt and the UK," in Natural Disasters and Development in a Globalizing World, edited by M. Pelling, London: Routledge, 141-156.

Ismail, Mawardi. 2005. "Beberapa Masalah Sosial dalam Proses Rehabilitasi dan Rekonstruksi Provinsi NAD," One Day Workshop, Reconstruction and Reconciliation for Aceh: Where To Go? Organized by. Tim Aceh bangkit, Gadjah Mada University February 22.

Muhammad, Gunawan. Tuhan pasca tsunami. Jakarta: Freedom Institute dan Jaringan Islam liberal, (www.Islamlib.com).

Pike, Nelson. (ed). 1964. Good and Evil. New Jersey: Prentice Hall, Englewood Cliff.

Pro Quest Eco-Disester or God's Wrath? Indians React to Tsunami.14/08/2006

Putra, Heddy Shri-Ahimsa . 2000. "Peringatan, Cobaan, dan Takdir: Politik Tafsir Bencana Merapi", Masyarakat Indonesia Jilid XXVI, No. 1.

Satkorlak provinsi NAD (Serambi Indonesia, Sabtu 19 Februari 2005)

Schuon, Frithcof. 1995. Transfigurasi Manusia, Refleksi Antrosophia Perenialis. Yogyakarta: Qolam press.

Sholeh, Muh dan Imam Musbikin. 2005. Agama Sebagai Terapi, Telaah Menuju Ilmu Kedokteran Holistic. Yogyakarta: Pustaka Pelajar.

Smith, Oliver and Hoffman, S. M. 1999. The Angry Earth: Disaster in Anthropolohical Perspective, New York: Routhledge.

Sola scriptura, Kanisius, Vol. 1, no 2 Februari-Maret 2007

Tylor, EB. 2000. "Animisme dan Magic," in Daniel L. Pall Seven Theory of Religion, Yogyakarta: Qolam Press.

www. Tutur.web.id/analisis bencana, July 19, 2006. 